\title{
Improving Access to Justice: Do Contingency Fees Really Work?
}

\section{Allan C. Hutchinson*}

While not touted as a universal panacea for access problems, contingency fees have received general praise as an important and justice-improving initiative. By back-loading the payment of legal fees, the assumption is that the interests of clients and litigants will be better served. I challenge that received wisdom. While the rise of contingency fee agreements between lawyers and clients has increased the number of people who can afford lawyers and make successful claims, the more challenging issue is whether that increase is being achieved at too high a price to clients and litigants - while more people are able to bring a case, which they could not otherwise have done, they will be receiving far less than they might actually be entitled to. In short, do contingency fees work as much or more to the advantage of lawyers than clients? I suggest not.

Bien qu'ils ne soient pas considérés comme une panacée aux problèmes d'accès, les honoraires conditionnels sont généralement reconnus comme une initiative importante qui permet d'améliorer la justice. Le fait d'assujettir le paiement des honoraires juridiques à certaines conditions est considéré comme une mesure permettant de mieux protéger les intérêts des clients et des parties aux litiges. Je conteste cette perception. Malgré le fait que la hausse des accords d'honoraires conditionnels entre les avocats et les clients a permis à un plus grand nombre de personnes de retenir les services d'un avocat et de faire valoir avec succès leurs revendications, il faut se demander si le prix que paient les clients et les parties n'est pas en définitive trop élevé : bien qu'un plus grand nombre de personnes soient en mesure d'engager des poursuites, ce qu'elles n'auraient pu faire autrement, elles recevront beaucoup moins que ce à quoi elles pourraient avoir droit en réalité. En d'autres termes, les honoraires conditionnels sont-ils aussi avantageux ou plus avantageux pour les avocats que pour les clients? Je fais valoir que ce n'est pas le cas.

\section{INTRODUCTION}

'Access to Justice' has rightly become a battle-cry for those who want to improve the delivery of legal services. One of the most enduring and genuine barriers to access is the high cost of lawyers. The plain fact is that many people simply cannot afford to pay the full price of legal assistance. As a result, their access to legal justice is severely diminished. Accordingly, without concerted efforts to deal with that system-wide issue in direct or indirect ways, the push for greater access will be destined to fail. There are, of course, many ways to achieve that end. One of the more established means to do that is the practice of contingency fees within personal injury litigation. As the ubiquitous advertisements have it, there is 'no fee, if no win': lawyers will not charge any fees unless the claim succeeds and, then, they will take a percentage of any award or settlement made. Indeed, while not touted as a universal panacea for access problems, contingency fees have received general praise as an important and justice-improving initiative. By back-loading the payment of legal fees, the assumption is that the interests of clients and litigant will

* Distinguished Research Professor, Osgoode Hall Law School, York University, Toronto, Canada. I am grateful to Eliza Coogan, Jennifer Leitch and other friends and colleagues for critical assistance and intellectual support. 
be better served.

In this short and provocative essay, I intend to challenge that received wisdom. While the rise of contingency fee agreements between lawyers and clients has increased the number of people who can afford lawyers and make successful claims, the more challenging issue is whether that increase is being achieved at too high a price to clients and litigants - while more people are able to bring a case, which they could not otherwise have done, they will be receiving far less than they might actually be entitled to. In short, do contingency fees work as much or more to the advantage of lawyers than clients? ${ }^{1}$ This essay is divided into four parts. In the first part, I look at contingency fees generally and their role in the legal process. The second part explores the traditional rationale for contingency fees. In the third part, I unpack and challenge the arguments used to defend the continuing use of contingency fees as a device to advance access to justice. Finally, the fourth part takes a more critical look at contingency fees from a consumerprotection perspective. An overriding theme throughout is that, if access is to be enhanced, then that access must itself be just. It will hardly help the overall improvement in 'access to justice' if the quantity of access is increased, but the quality of justice is impaired or reduced.

\section{THE COSTS OF JUSTICE}

The expense incurred in staffing and maintaining the courts is met largely by the state, with the litigant paying only a minimal sum to utilize these facilities. The major financial burden incurred by the parties is the cost of legal services. A lesser expense is the payment of incidental expenses, so-called disbursements, that are incurred throughout the pursuit of a claim. In allocating this burden, the legal system has two alternative solutions. It can permit costs to lie where they fall and leave parties to pay their own costs, regardless of the outcome of the claim, or it can order that costs should follow the event and require the unsuccessful party to pay the costs of the successful party. Whereas the Americans have adopted the former as a general rule, the Anglo-Canadian legal system has opted for a general rule of indemnity. It is generally acknowledged that a successful party will receive about 50-60\% of the actual legal fees incurred.

Although contingency fee arrangements [CFAs] are a long-standing feature of the American litigation system, they have only been allowed in Canada in more recent decades. This reflects an historical antipathy in the Anglo-Canadian system to allowing contingency fees agreements because they are generally thought to encourage lawsuits. The basic hostility to contingency fees as a form of champertous agreement is captured by Spiegel J.'s statements in Bergel \& Edson v. Wolf:

Rules against maintenance and champerty were introduced over 700 years ago in response to abusive interference in the legal system by powerful royal officials and nobles. Although the particular abuses against which the prohibitions were directed had been cured by the time of the Tudors, the rules continued to survive. In modern decisions concerning maintenance, courts do not refer to the mediaeval origins of the doctrine, but justify its continued existence on the basis of public policy considerations. The antipathy of the courts to champertous agreements similarly is supported by policy concerns. In these expressions of policy are the roots of the arguments justifying the present ban on contingent fees. ${ }^{2}$

1 My focus is not on the operation of any particular scheme of contingency fees (as they differ slightly from one jurisdiction to another). Rather, I am more concerned with the overall thrust of the idea and operation of contingency fees. That said, I have limited my reference to Ontario cases.

2 Bergel \& Edson v Wolf (2000) 50 OR 3rd 777 at para 22. For a general history from an Ontario standpoint, see Andrew Murray, Contingency Fees What Is Old Is New Again (4 March 2005) Presented at the Trial Lawyers Association MVA 
Nevertheless, a proportionate relation between fees and the amount of damages awarded has always played a role in fee arrangements, even if a limited and understated one. For instance, in Cohen v. Kealey $\&$ Blaney in 2000, the Ontario Court of Appeal affirmed a list of considerations to be taken into account by an assessment officer when conducting a fee assessment -- the time expended by the solicitor; the legal complexity of the matters to be dealt with; the degree of responsibility assumed by the solicitor; the monetary value of the matters in issue; the importance of the matter to the client; the degree of skill and competence demonstrated by the solicitor; the results achieved; the ability of the client to pay; and the client's expectation as to the amount of the fee. ${ }^{3}$

The basic rationale for allowing any kind of CFA is that it allows people who cannot afford legal services to bring claims that they would otherwise have to forego or abandon. This general policy objective seems unimpeachable in its logic and effect. Parties will be able to proceed in the confidence that they will not have to make up-front payments to lawyers by way of retainers and that they will not be left with an enormous economic burden if their claim fails. Of course, this state of affairs is premised on the high cost of legal services - lawyers' fees are often perceived to be prohibitive by many potential litigants, especially when they are already injured or indebted. That said, it also must be recognized that lawyers should be entitled to a reasonable rate of compensation for services rendered. Whatever the collective responsibility of the legal profession for this state of affairs, it is simply unjust to expect individual lawyers to volunteer their services or to accept less for their services than otherwise would be the case.

\section{CONTINGENCY FEE AGREEMENTS}

The challenge is to ensure that the benefits of CFAs to litigants are not obtained at an exorbitant cost and that a balance is struck and maintained between the advantages of more claims being litigated and the costs of doing so. In other words, any legitimate regime of CFAs must work to ensure that both sides of the equation, litigants and lawyers, are balanced. Access to justice should be obtainable at a reasonable cost and lawyers should be entitled to fair compensation for their services, but they should not be allowed to obtain undue financial benefit from the plight of impecunious or vulnerable litigants. In short, although promoted as a device to benefit litigants, CFAs must not be permitted to operate to prioritize the financial interests of lawyers over litigants. When a lawyer is paid a percentage of the settlement amount (with the settlement amount often equaling the insurance limit), a lawyer's financial incentives will vary considerably. Under the traditional billing regime, a lawyer knows that he or she will be paid in accordance with the work that they have done. While this will not in practice be calculated regardless of the outcome, there is an assurance of some payment.

While this traditional approach to fees presents some risk that the client will not pay, most lawyers finesse this possibility by requiring retainers up-front. Indeed, under the traditional arrangements, there is a genuine concern that lawyers will have an incentive to do more work than a file may require. Under a CFA, a lawyer will face a very different set of incentives. This is because, irrespective of the amount of hours the contingency fee lawyer puts in, the lawyer will be paid a percentage of the settlement or judgment amount. While this may incentivize them to ensure that their client wins a substantial amount, they will also be disincentivized from putting in 'too much' time since their compensation remains fixed. Indeed, the economically optimal approach of lawyers is to ensure that their efforts will lead to an improved resolution of the case, but only up to a certain point. In other words, rational lawyers under

Conference, online: Docplayer < http://docplayer.net/641275-Is-old-is-new-again-contingency-fees-by-andrew-cmurray-london-ontario-presented-conference-march-4-2005-box-2335-n6a4g4-phone-519-640.html >.

3 Cohen v Kealey \& Blaney (1985) 26 CPC (2d) 211 [Cohen] at 215. 
CFAs will strive to maximize their compensation by constantly assessing the cost-benefit of proceeding further in the case. The cost can simply be seen as the amount of hours the lawyer puts into a case, while the benefit is their percentage of the total settlement amount. A potential conflict of interest arises if the lawyer's incremental financial benefit from proceeding further will cause the lawyer's effective hourly rate or total compensation to fall.

According to Richard Posner, the doyen of law-and-economics scholars, the lawyer is effectively a "co-tenant of the property represented by the plaintiff's claim" and therefore "may lack an adequate incentive to exploit the right (to litigate) because the value he creates will accrue in part to another person." ${ }^{4}$ Indeed, this may well incentivize lawyers to settle too early. Again, Posner offers a good example of this:

"Suppose the plaintiff's lawyer is offered a settlement of $\$ 100,000$; if he goes to trial, there is a 90 percent chance that the plaintiff will win $\$ 150,000$ but it will cost the lawyer $\$ 25,000$ worth of his time to try the case; the parties are risk averse; and the contingent fee is 30 percent. If the plaintiff agrees to the settlement, he will net $\$ 70,000$ and the lawyer $\$ 30,000$. If the case goes to trial, the net expected gain to the plaintiff rises to $\$ 94,500(.9 *(\$ 150,000$ - $\$ 45,000)$ ) but the lawyer's net expected gain falls to $\$ 15,500(\$ 45,000 * .9-\$ 25,000)$. So there is a conflict of interest between the parties that is due to the fact that the lawyer does not obtain the whole benefit of a trial (the expected net benefit of trial is $(\$ 50,000$ * $.9)$ - $\$ 25,000$, and is thus positive). ${ }^{, 5}$

In accordance with this perspective, it can be argued that lawyers should be entitled to receive a higher fee than might otherwise be the case since they are seeking to spread the risk across a range of cases that have no guarantee of success. So, in assessing the fairness of any fee received by a lawyer under a CFA, it is important to acknowledge that, in some cases, a lawyer will invest considerable time and effort in a case that does not produce any or sufficient funds to cover the time expended by the lawyer. However, as Posner puts it, this "risk is reduced because the lawyer specializing in contingent fee matters can pool many claims and thereby minimize the variance of the returns." Accordingly, in order to assess the overall fairness of lawyers' compensation from CFAs, it would be necessary to obtain data on all files covered by CFAs to ascertain the relative number of 'losing' cases (i.e., the lawyer receives no fees) that are undertaken by lawyers as well as the relative number of 'winning cases' that are undertaken. ${ }^{7}$

There is also the considerable problem of conflicting interest and so-called double-dipping. In any settlement negotiations, the defendant lawyer will usually only be interested in the amount of the global payment made. On the other hand, the plaintiff's lawyer will have an acute interest in how that lump sum is to be apportioned. If the plaintiff's lawyer is simply going to take a flat percentage fee, then there is little problem. However, there is a problem if the plaintiff's lawyer is entitled not only to a percentage of that sum, but also to all of the costs. While the plaintiff's lawyer will benefit from maximizing the portion allocated to costs, the client will not; the client's interests are best served by minimizing the amount of costs and maximizing the amount apportioned to damages. So, if there is a settlement agreement for a global amount of $\$ 100,000$, a plaintiff's lawyer working on a flat percentage fee of $25 \%$ would receive

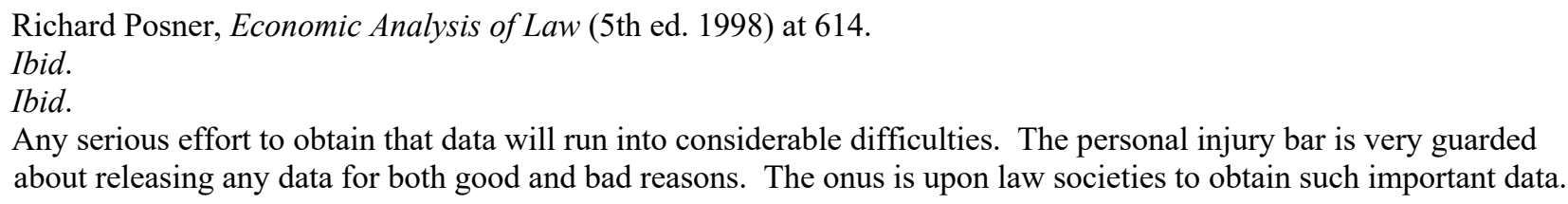


$\$ 25,000$. However, if a plaintiff's lawyer had agreed to a percentage fee of $25 \%$ and all costs, that lawyer would receive much more. Assuming that a settlement had been made for $\$ 100,000$ and apportioned at $\$ 75,000$ for damages and $\$ 25,000$ for costs, a plaintiff's lawyer would receive $\$ 43,750$ (i.e., the $\$ 25,000$ for costs plus $25 \%$ of the $\$ 75,000=\$ 18,750$ for a total of $\$ 43,750)$. Although this is a stark example, it demonstrates how conflicting interest might result in double-dipping - the lawyer gets more than about $75 \%$ of what the client receives (i.e., $\$ 43,750$ to $\$ 56,250){ }^{8}$

At the heart of any inquiry into contingency fees is the central question of whether the benefit to plaintiffs of entering a CFA is being obtained at too high a price to them and at too large an advantage to lawyers. Litigants may gain from CFAs in that they can litigate in circumstances where they would otherwise not be able to do so. That said, it must not be to the greater comparative advantage of lawyers who might receive an unearned windfall in the fees received. In short, is the price of access to justice still too high? Are lawyers, not claimants, the big winners under the present regime of CFAs?

\section{FIXING THE BASE}

A major challenge in making a sensible and reasoned assessment of CFAs is the need to develop a base-line level of compensation against which any changes in the traditional billing arrangements can be measured. One possibility recommends itself - to measure what happens across files that have CFAs against what those files would have generated by way of fees if they had been billed on a traditional hourly basis. Consider that a lawyer charges an hourly rate of $\$ 300$; this is about average for an urban personal injury lawyer (and perhaps is a little conservative). This figure could be said to represent what the lawyer thinks is a reasonable and achievable rate (less substantial overheads) for their services. The precise amount will vary from lawyer to lawyer, but this is not important for illustrative purposes; I make no comments on whether this level of remuneration is considered to be defensible or not as a general matter. If that lawyer only worked on a traditional hourly basis, they might bill $\$ 600,000$ annually if they worked 40 hours per week for 50 weeks (i.e., 2000 hours multiplied by $\$ 300$ per hour).

The total of $\$ 600,000$ would presumably be arrived at as the cumulative total for both 'winning' and 'losing' files. ${ }^{9}$ If lawyers were to earn substantially more than this, then they would seem to be taking advantage of those clients who were obliged by circumstances to enter into such CFAs. If they were to earn substantially less than this, then they would be providing their services at a discounted rate. Allowing for some marginal deviance from the mean (i.e., \$550,00 and 650,000), it would seem that neither of these situations would be fair. Accordingly, CFAs can be evaluated as being fair or not in terms of their effect on the overall remuneration received by lawyers when measured against the number of hours worked.

As this simple illustration shows, the two key factors in evaluating lawyers' remuneration are the hours worked and fees actually received. Although the courts have been prepared to look to other factors (e.g., the legal complexity of the matters dealt with; the monetary value of the matters in issue; and the results achieved), ${ }^{10}$ it would seem that these factors are folded into the hourly fee able to be charged by the lawyer and the amount of work required to be done by the lawyer. The more competent the lawyer and the more successful she or he is, the more that the lawyer will be able to charge clients. Assuming, therefore, that the lawyer is content with $\$ 600.000$ as an acceptable level of remuneration for the hours of work done and

See e.g. Hodge $v$ Neinstein, 2015 ONSC 7345. The courts have now outlawed such practices.

9 By 'losing' and 'winning' cases, I do not only mean to include those files that are either fully successfully or completely unsuccessful. By winning, I mean that clients will receive a sizeable amount after their lawyer has been paid that will go a substantial way to compensating them fairly for their claims and harms.

10 See Cohen supra, note 3. 
the type of work done, it also seems reasonable that a broadly similar amount should be earned annually under CFAs. Of course, this is, by necessity, very much a speculative exercise. Any information on the earnings of lawyers, the fees charged, and the hours worked can only be the subject of conjecture and anecdote. This lack of information is troubling in itself for a profession that benefits from public regulation and protection. However, I maintain that it is feasible to make a tentative analysis and to draw certain conclusions. While the available information does not lend itself to rigorous or quantitative analysis, its analysis makes for suggestive reading and reveals some tendencies and trends.

There are three important factors in play in determining the fairness of contingency fees - the actual number of hours worked on a file; the amount of money that is produced by winning files; and the number of hours worked, but not charged for on losing files. These factors interplay in important and complex ways. For instance, a lawyer may spend relatively few hours working on a file, but achieve great success and, therefore receive a very large premium on the usual fees that they would charge. So, on a case that gives rise to a $\$ 100,000$ settlement, but only demands 20 hours of work, a lawyer might well recover $\$ 25$ 30,000 in fees; this would represent an hourly rate of over $\$ 1,250$ per hour. One ethical problem here is that, as well as allowing the lawyer to receive a massive premium on their regular fee of $\$ 300$ per hour, the lawyer might be misleading the client in suggesting that a contingency fee is a reasonable way to proceed on a file that the lawyer has a reasonable sense that it will require only a relatively few hours of work to achieve a very lucrative outcome (for both lawyer and client).

Conversely, it might be that the lawyer is mistaken in the initial assessment about the amount recoverable on a file, the chances of success, and the number of hours that will need to be done to achieve that favourable outcome. So, on a case that the lawyer initially thinks that there is a high likelihood that it will give rise to a $\$ 100,000$ settlement and demand only 20 hours of work, an error of judgment will be significant for the lawyer's remuneration. Even if the file produces a settlement of $\$ 20,000$ and the lawyer, therefore, receives $\$ 5-6,000$ in fees, the lawyer might well have invested more than 50 hours of work; this will mean that the lawyer will end up with an hourly fee of only slightly more than $\$ 100$ per hour. This would not be a fair outcome for lawyers and provide little incentive for entering into further CFAs with future clients.

To play out this example and its underlying logic more fully, assume that that the lawyer only did contingency work. If that lawyer were to take on numerous files and had a $50 \%$ success rate, they would be entitled to charge an amount to their clients that would average out to $\$ 600$ per hour (or twice their normal fee of $\$ 300$ ) for the winning cases. This would result in them receiving their usual and average level of annual billing if they were billing on an hourly basis (i.e., \$600,000). If that lawyer's success rate was $75 \%$, they would be entitled to charge an amount that would average out to $\$ 400$ per hour (or $1 / 3$ rd or $33 \%$ over their normal hourly fee) for the winning cases. This would result in them receiving their normal level of annual billing of $\$ 800,000$ if they were billing on an hourly basis.

From a critical perspective, there are two central problems with this - it assumes (1) that the amount of fees that the lawyers receive in winning cases bears some proportionate connection to the hours actually worked; and (2) that lawyers are taking on a significant number of losing cases. As regards the first problem, there is little information available to determine whether there is a connection, however general, between the fees received and the hours worked. Under most CFAs, there is no requirement for such a connection to exist; lawyers are under no obligation to justify or even explain the fairness of the fees received in terms of the actual time spent on the file. Of course, this disconnection might well become more stark as the amount involved in the dispute increases. It is surely the case that the amount involved on a file, the complexity of the legal work, and the hours worked are not necessarily interwoven. Whether the case is worth $\$ 10,000, \$ 100,000$ or $\$ 1 \mathrm{M}$ does not in and of itself control the amount of work required 
to be successful. Although a $\$ 1 \mathrm{M}$ case might take more time than a $\$ 10,000$ or $\$ 100,000$ case, there is little reason to assume that it will take 100 or 10 times more work.

As regards the second problem, there is also little evidence that lawyers are taking on a high percentage of losing cases. However, much of the discussion about CFAs seems to proceed on the very untenable assumption that lawyers take on all cases and clients that come into their offices. It would defy logic, reason and experience to so assume. It would be foolhardy for lawyers to accept files that either have little chance of success or would demand a very high amount of hours to succeed. The prospects of a high settlement or judgment might persuade some lawyers to take on a more risk than in files where there is a lower final outcome and, therefore, less fees will be forthcoming as a percentage of that outcome. However, this will still be highly constrained by the number of hours that are anticipated to be worked in order to effect such a favourable outcome. That said, it would remain rare for lawyers to take on files where the chances of losing are substantial as the effect of taking on losing cases is so dramatic (i.e., no remuneration for work done). Consequently, it can be assumed that most lawyers are only taking on cases and files through a CFA if the odds are strongly stacked in favour of a successful outcome and, preferably where the size of that outcome is larger and the amount of hours worked are lower. While there is no genuine supply of information to confirm or deny this, these observations only stand to business reason.

Nevertheless, lawyers still make arguments before courts and regulators that the existence of losing cases warrants a very substantial mark-up in the fees charged and received. However, it is telling that there is no information available or proffered that backs up such an important and dubious rationale. While there are cases in which courts have demanded that lawyers provide information about retainers and dockets, this is far from standard. ${ }^{11}$ After all, most CFAs are made and enforced without any involvement by courts. Indeed, there are many instances where courts have actually spoken against a reliance on time dockets and any connection between the fees received and the hours worked. Whereas one court noted that "the determination of the proper fee in a CFA is not based on the value of the time spent, but rather on the amount recovered for the client," 12 another court went so far as to say that "using a percentage calculation in determining class counsel fees properly places the emphasis on the quality of representation, and the benefits conferred to the class" and that "a percentage-based fee rewards 'one imaginative, brilliant hour' rather than '1000 plodding hours'."13

\section{A CONSUMER PERSPECTIVE}

It is now fully accepted that consumers need to be protected against the greater economic and bargaining power of large merchants and corporations in the marketplace. There is consequently a detailed and comprehensive set of protections and entitlements (e.g., standard terms, enhanced remedies, etc.) in both statute and common law that serve to guard the consumer against disreputable and exploitative practices. If there is a case for such safeguards in the general market (which there surely is), then there is an even stronger case for protections and entitlements in regard to dealings between lawyers and potential clients. Both individually and collectively, lawyers operate in a protected and specialized environment that bestows privilege and power upon them. As part of any social compact, it seems entirely reasonable that, in acting in the public interest, lawyers have responsibilities and duties to the people they act for and serve.

In this regard, there are three particular considerations that spring to mind -- the enforcement of legal

11 See e.g. Young (Litigation Guardian of) v Hinks Estate, 2010 ONSC 2067.

12 Henricks-Hunter (Litigation guardian of) v 814888 Ontario Inc, 2012 ONSC 4564.

13 West Coast Soft Wear Ltd v 1000128 Alberta Ltd, 2010 ONSC 6388. 
rights is a mainstay of society's commitment to democracy and the Rule of Law and should be facilitated, not hampered by lawyers; the stakes are extremely high for clients, especially those with personal injuries, who are seeking compensation and recourse for damages caused by the wrongdoing or negligence of others; and lawyers hold a monopoly as gatekeepers to the legal process and, therefore, have complementary duties to the public. This combination of factors means that, at a minimum, there should be appropriate and similar protections in place for lawyers' clients as in the general consumer context. However, given the particularly pivotal role of lawyers in the social and political process, protections in the legal context should perhaps be elevated: there are few groups that have such a pivotal role in the social and political process.

When persons with personal injuries seek legal assistance to pursue any claims available to them, they are doubly vulnerable. Not only is there an obvious and large imbalance in knowledge and power between them and lawyers in regard to the validity, strength and viability of their claims, but they are also in a debilitated and injured state. In such circumstances, it is essential that the system operates to ensure that they are not further taken advantage of, especially by their legal advisers. Insofar as lawyers hold themselves out as a 'noble profession' with social duties and responsibilities, they are not simply another business in the marketplace. Accordingly, it is incumbent on the system, both by way of legislation and professional regulation, to take decisive steps to ensure that the interests of clients are given the fullest protection against exploitive and unfair practices and that, conversely, lawyers are restrained from and penalized for engaging in such practices.

As things stand now, it cannot be confidently reported that the present scheme in regard to CFAs is operating to protect and advance the interests of clients in their dealings with lawyers. Indeed, the existing scheme of contingency fees is allowing lawyers to recoup much larger fees than they otherwise might do under the normal hourly-fee arrangements for services rendered. Again, while lawyers are fully entitled to receive fair and reasonable fees for the services that they render, there is no plausible case for insisting that lawyers should be able to cash-in on the opportunities that CFAs afford for enhancing their fees. Indeed, as contingency fees presently work, there is a concern that the major claim that underpins the legitimacy and value of contingency fees to advance access to justice is largely unsupported and unsubstantiated -- that lawyers take on a significant number of unsuccessful cases, such that the lawyer does not receive adequate fees for the time expended on the file.

Any defence of the existing system demands that this claim be supported. Unless there is a significant number of 'losing cases', the argument in favour of allowing lawyers to receive more by way of fees than they otherwise would do so becomes unpersuasive. Secondly, unless personal injury claimants can enter other kinds of fee-arrangements with lawyers and not be simply presented with a take-it-or-leave-it CFA (even a balanced and reasonable one), they are being exploited by the legal process. The capacity to make genuine and informed choice is a basic standard that consumers are accorded in other commercial settings. It is simply unacceptable and against the public interest to have less than that in the lawyering and rightsenforcement context. The legal profession as much as the public at large has a serious interest in ensuring that 'access to justice' is real, and not simply a vague ambition.

\section{CONCLUSION}

My brief in this essay has been to question the received wisdom that contingency fees are a tried-andtrue device for improving access to justice. In my opinion, they increase the number of litigants, but only at a very high price for the clients and litigants; lawyers are the primary beneficiary of such a costs device. Although there is admittedly little data available to reach any hard-and-fast conclusions, the onus is on 
lawyers to establish that there is some correlation between hours worked and fees received and that they do take on more than a handful of losing cases. As things stand, it would be wrong-headed for the legal process to proceed on the basis that both these facts are true. There are many things, large and small, that courts and regulators could do to improve the situation - introduction of a fee-multiplier for successful cases rather than a straight percentage; filing of all CFAs with courts; the sampling of the operation of CFAs by courts; and the obligatory use of standard-form CFAs. Until and even when such reforms are made, it is incumbent on the legal profession to demonstrate that contingency fees truly contribute to advancing 'access to justice' rather than giving only the false appearance of doing so. 